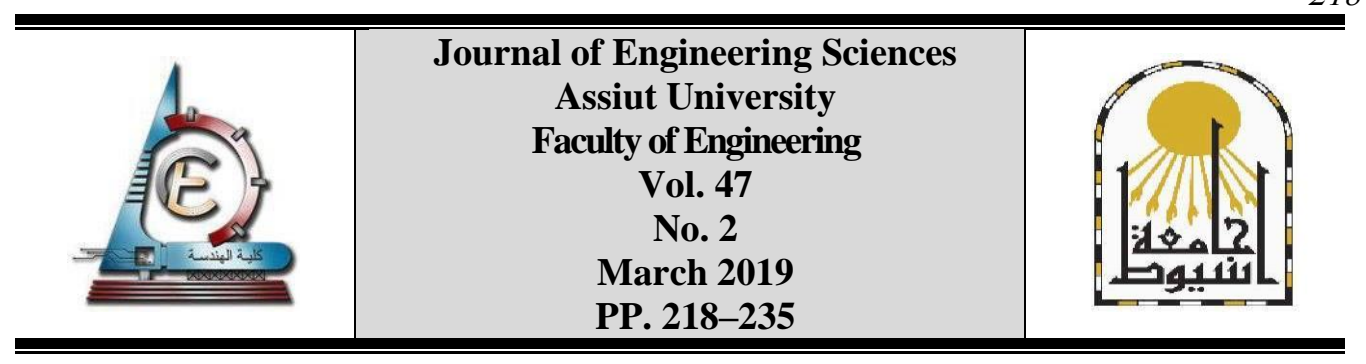

\title{
DESIGN AGAINST VANDALISM AS A NEWAPPROACH TO LANDSCAPE MAINTENANCE IN URBAN OPEN SPACES
}

\author{
Reham Othman El Sayed
}

\begin{abstract}
Architecture Depart - The higher Institute for Engineering and Technology - New Cairo
\end{abstract}
Received 28 October 2018; Accepted 27 November 2018

\begin{abstract}
Urban open spaces are places located and designed within the context of urban and landscape design that provide to people opportunities in the urban environment. parks has been a major focus in promoting places for relaxation and recreation. Urban parks therefore can be regarded as public spaces, which cater to the needs of urban dwellers and the community as a whole. In other words, parks were designed to promote public health and to give some aesthetic value to an urban setting, That makes it necessary to pay special attention to the organization of these open spaces. All the factors concerning planning should be considered and evaluated at the planning stage of the urban open spaces. One of the common deviations in our current societies is vandalism. Vandalism is a philosophical approach that affected on landscape elements in urban open spaces. It can affect people's quality of life because it damages or destroys elements that they need or care about. It also Makes people feel that their lives are less safe than they really are. Thus it is necessary to identify the effective factors on the reduction of this phenomenon as a new approach to emphasize the new concept "Design against vandalism ". The purpose of this paper is to analyze vandal reasons to find design factors and proof that applied designer suggestions can be a solution to face this phenomenon towards landscape elements in urban open spaces. And it should be evaluated as a part of maintenance, functional uses and user's activities which based on landscape elements.
\end{abstract}

Keywords: Urban open spaces -Vandalism phenomena - Vandal behaviors -Landscape elements - landscape maintenance tasks

\section{Introduction}

Urban open space drive human behaviors are certainly fact therefore It is necessary to design urban space with consideration of human objectives. This paper is based upon the idea that the environment influences people's behavior and uses design principles to reduce the potential for negative behavior to occur. Therefore, principles should be incorporated at the design stage of a development but can be applied to existing spaces and areas.

Vandalism, which means destruction of the urban environments and its landscape elements, is an awkward phenomenon. This phenomenon has reached a dramatic growth in human society and the ways in which we can confront according to the perspective that we choose. The problems that people face in their daily life are continuously increasing, and people's resistance to these problems is gradually decreasing. This paper is concerned with the effects of vandal behaviors on landscape elements of the public open spaces and factors that need to be considered 
when designing such spaces to minimize vandalism. To assess the effects of vandalism on increasing maintenance landscape tasks. The results indicate a relationship between the importance of applied design factors and reduce the maintenance of the elements gradually either by preserve life cycle or reduce the replacement, repaired and painting operations.

\subsection{Problem definition}

Vandalism is considered as a problem that stems from disturbances in urban environments. It may be related to the socioal behaviors and lack of urban management in public spaces.Vandalism phenomena, which is one of the ways of expressing a person's psychological and social uneasiness, can not be completely prevented. However, designers can minimize the occurrences and outcomes of vandalism by taking human behaviors into account and setting positive precautions.This paper is concerned with identify and understand vandalism issues that occur in urban open space towards landscape elements as well as to accessing the impact of applying the recommend list adopted by Collin Yard that deals with design against vandalism to deduce this phenomenon against landscape elements. and show its impact on reduce some of maintenance tasks. This linkage is considering the prospected contribution of this paper.

\subsection{Objectives}

The purpose of this paper was to analyse the vandal actions may occour against landscape elements and its different reasons as step to access some of design suggestions used in design of landscape projects which can be applied in design phase or phase of choosing raw material to reduce some of vandal actions. In addition, the study intended to investigate the relation of applied landscape design suggestions during design phase and the reduction of landscape maintenance tasks.

\section{Methodology}

The research use the Inductive approach in theoritecal part to reach the thioretical Primary data which collected by observations and analysis the main definitions and different classifications. Secondery data use the empirical approach (Statistics inference) were gathered by questionnaires and in depth interviews. The empirical part is based on survey of two sample as landscape projects examples (Two main gardens in Egypt that faced the phenomena of vandalism) to explain the effect of faced vandal actions on different maintenance course.

\subsection{Types of respondents}

The main idea of this paper is relevant to different stakeholders including users, psychologist, landscape engineers and workers of landscape gardens from two locations: the zoo and Azhar park, Cairo (as shown in table 1).

\subsection{The design of questionairs}

The resarch objectives analysed in two tables:

- The first table was distributed among 100 of stakeholders to measure Percentage of reasons of vandal action differ between design mistakes or users' behaviors depends on user's culture, Psychosocial and community around them, The table contains 28 printed photographs represented landscape vandal actions may occur against landscape that were classified by collien representable in 3 
different categories of landscape elements. The selection of these pictures is driven from the classifications of vandal actions to prove that it is not a local problem, but a global one. So, some of international magazines and websites written about it. The sites are landscape national or international gardens faced the vandalism phenomena, the pictures describe vandalism in three gardens only (George Washington Park -The Zoo and the Azhar Park, Egypt).

- The second table was distributed among 50 landscape design and maintenance engineers and workers formed as a questionnaire conists of 28 design suggestion to measure the effect of applying it on different maintenance task.

\section{Table 1.}

The sample characteristics - source :Author

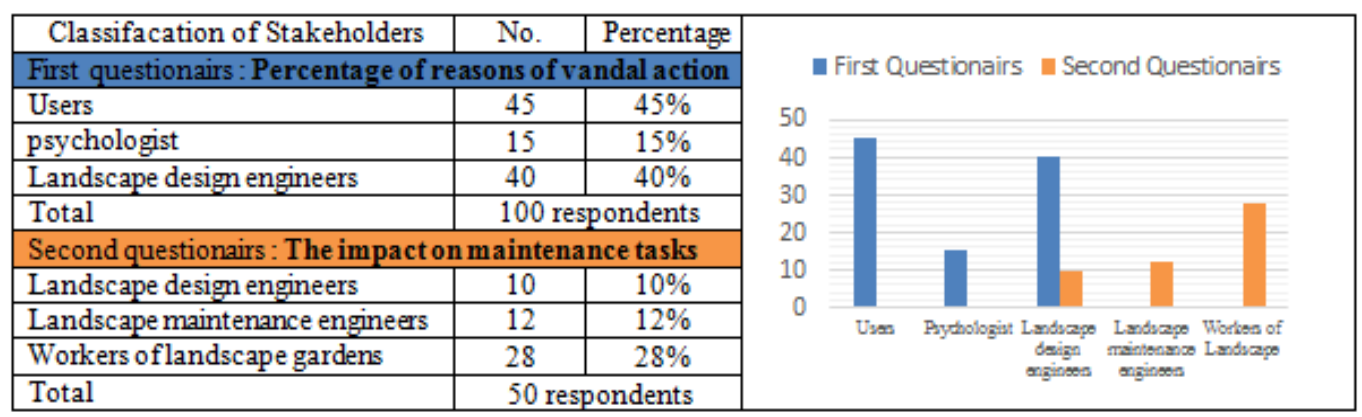

\subsection{Analysis of data}

Results represented as tables and charts, The charts according to the probability theory which is the chance that something will happen - how likely some event will occur. Which is defined scientifically as number of occurrences divided by total number.

\section{Urban open space}

The term 'urban space' can be simply described as external space in town. It is seen as open, unobstructed space for movement in the open air, with public, semi public and private zones. Furthermore, the 'concept of urban space' is to design all types of space between buildings in towns and other localities as urban space. If we take the aesthetic criteria into consideration, every urban space has been organized according to its sociopolitical and cultural attitudes -Rob Krier [1]. There are Various types and subtypes of urban open spaces. These different types bring different functions and characteristics. Understanding diverse types and roles of urban open spaces helps urban planners and designers to recognize how to develop and manage it, and to improve their effectiveness [2]. Therefore, it is necessary to have reliable definition and approaches to the valuation of open spaces in order to understanding its importance.

\subsection{Importance of urban open space}

Open spaces within and near urban centers increase livability and enhance property values. The mental and physical health benefits of parks and green spaces have been demonstrated and can be proven to be actual preventative measures that impact positively on health care. Green open spaces can be considered an area's "lungs" that reduce the effects of air pollution. The protection of natural areas can help resolve water-related environmental problems[3]. The benefits that urban open space provides to citizens can be broken into five basic forms: 
- Functional importance: Give the opportunity to practice human activities.

- Environmental importance: Green spaces also are important to mental health.

- Social importance: Create chances for interaction between people.

- Aesthetic importance: Preserve natural beauty.

- Economic importance: provide places for economic activities, increase price of surrounding units.

\subsection{Human behaviors in urban space}

The urban spaces contain the humans that interact with each other on the based on a series of the social norms and values, and the condition of the survival of the society is to accept and internalize these norms and values, and any violation of them is considered as deviation [4].

As the behavior of users directly affect the spaces, these behaviors either to be positive or negative on the space used as strong indicator to meet the requirements of the spaces ,as shown in Fig.1. Thus, the behavior of individuals within spaces can be divided into:

- Positive Behavior: Behaviors that reflect the correct use of open spaces and the correct handling of each element in the way that is designed for (practice activity in specific place in a true way ).

- Negative behavior: behaviors that reflect the incorrect use of open space elements and the failure to deal with the element in the manner designed for (practice activity in another place). Vandal behavior: Behavior resulting from the disadvantages of design interaction with users and may be due to other reasons, including design, psychological factors and or learned behaviors [5].

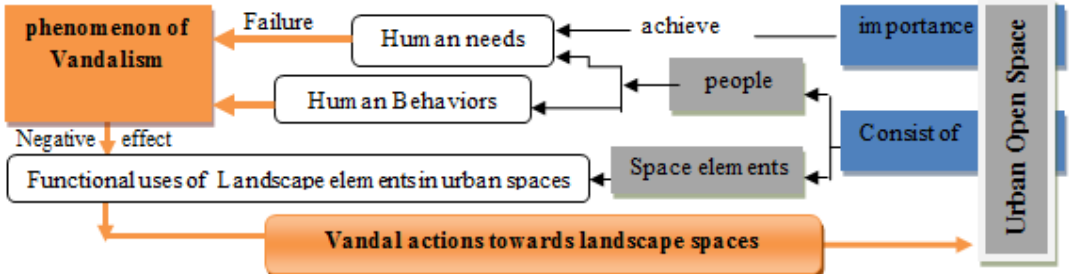

Fig. 1. The effect of achieving human needs and human behavior on using the landscape elements in urban spaces- source :Author.

\section{Vandalism against landscape}

Vandalism refers to "destruction of public places and properties in the city" - Longman, 2003 [6] , The causes of vandalism categorized into internal and external ones. Internal causes refer to inherent characteristics of the objects and urban spaces and to the internal and individual characteristics of the people. On the other hand, external characteristics refer to environmental and social factors that play a key role in bringing about the desire for vandalism. Some scholars who emphasize the role of social factors in the environment say that vandalism is the reaction of people towards the environment because of their dissatisfaction towards the place they live in. It also represents a kind of crisis in social interactions, through which the lack of belonging is expressed towards the spaces [5]. In a similar manner, some have emphasized the lack of sense of belonging towards public properties because of which vandalism is an epidemic phenomenon that has crept into many city environments. The most important reason for vandalism occurring is that people do not have any sense of ownership towards public property -Moradi, 2002 [6]. 
Hirshi, one of the pioneers in social control theory has considered vandalism as like other forms of crime which is caused by lack of social control and observation. He believes that, when the social control decreases, social unity will consequently diminish. Turvey, 2005. Dr.Monty Christansen, University of Pennsylvania identified the most target elements of landscape suffer from vandalism : Plant elements -Walls Electrical outletsTrash units - Fountains and water taps - Fences - Umbrellas and pergolas - Seats - Lighting units -Signboards, his research leads to the identification of the objectives was the first step to prevent vandalism followed by identifying elements raw materials [7] .Another study result was vandal actions focused on the benches, lighting elements such as lampposts, sunshade elements and picnic tables. Types of the park furniture, their current conditions, and relative positions have been used as the object of observation.

\subsection{Classification of landscape elements due to vandal actions}

Landscape elements divided into two main parts Softscape which consist of planet and water elements types and Hardscape elements which consist of paths, lighting units, sitting areas.... etc. It's important to classification landscape elements in the study upon user's vandal actions which may occur [8], and analyze the reasons of actions whether it is due to weakness in design or individual psychosocial or learned user's behaviorsas (use first Questionnaire), as shown in Table 2 - Table 3 -Table 4.

\subsubsection{Planet Elements}

Planet materials are extremely important physical elements in the design and management of outdoor environment. It provides a touch of life and beauty of an environmental due to the different effects of its nature (texture-color-height-spread-smell). The term "planet material" is used to represent native and cultivated woody planet of all types from ground covers to the trees [9].

Table 2.

Classification of Planet elements due to vandal actions - source :Author adapted by Collin Yard.

\begin{tabular}{|c|c|c|c|c|}
\hline$\stackrel{[t]}{a}$ & & Vandal Actions [8] & $\begin{array}{l}\text { Reasons of Actions } \\
\text { (Comments of questionnsire) }\end{array}$ & $\begin{array}{c}\text { Result of } \\
\text { Ouestionnaire }\end{array}$ \\
\hline \multirow{11}{*}{ 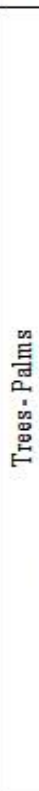 } & \multirow{4}{*}{$\begin{array}{l}\text { 1.Climb trees } \\
\text { and palms- } \\
\text { Fig. } 2 \text {. }\end{array}$} & \multirow[b]{4}{*}{$\begin{array}{l}\text { Fig.2. Source: The Zoo,Egypt } \\
\text { https://www.youm7.com/story/2018/2/3 }\end{array}$} & Design Mistakes & \multirow{4}{*}{$\begin{array}{l}\text { Wandal Behaviors } \\
\text { wesign Mistakes }\end{array}$} \\
\hline & & & $\begin{array}{l}\text { Not using } \\
\text { entertainement } \\
\text { elements for users. }\end{array}$ & \\
\hline & & & Vandal Behavior & \\
\hline & & & $\begin{array}{l}\text { Individual psychosocial } \\
\text { or eamed behaviors. }\end{array}$ & \\
\hline & \multirow{4}{*}{$\begin{array}{l}\text { 2.Scratch trees } \\
\text { andpalms - } \\
\text { Fig. } 3 \text {. }\end{array}$} & & Design Mistakes & \multirow{4}{*}{$\begin{array}{l}\text { W Vandal Behaviors } \\
\text { w Design Mistakes }\end{array}$} \\
\hline & & & & \\
\hline & & & Vandal Behavior & \\
\hline & & $\begin{array}{l}\text { Fig.4 source https://fox } 59 \text {.comVandals } \\
\text { strike .George WashingtonPark,2017. }\end{array}$ & $\begin{array}{l}\text { Individual psychosocial } \\
\text { or eamed behaviors. }\end{array}$ & \\
\hline & \multirow{3}{*}{$\begin{array}{l}\text { 3. Write or } \\
\text { picking flowers } \\
\text { andleaves, } \\
\text { Fig. } 4 \text {. }\end{array}$} & $E$ & Design Mistakes & \multirow[b]{3}{*}{$\begin{array}{l}\text { Wandal Behaviors } \\
\text { = Design Mistakes }\end{array}$} \\
\hline & & & & \\
\hline & & $\begin{array}{l}\text { Fig.4 source https://fox } 59 \text {.comVandals } \\
\text { strike .George WashingtonPark,2017. }\end{array}$ & $\begin{array}{l}\text { Individual psychosocial } \\
\text { or eamed behaviors. }\end{array}$ & \\
\hline
\end{tabular}


Table 2. (Cont.)

\begin{tabular}{|c|c|c|c|c|}
\hline 년 & & Vandal Actions [8] & $\begin{array}{l}\text { Reasons of Actions } \\
\text { (Comments of questionnaire) }\end{array}$ & $\begin{array}{c}\text { Result of } \\
\text { Questionnaire }\end{array}$ \\
\hline \multirow{4}{*}{$\frac{v^{2}}{\frac{1}{2}}$} & \multirow{4}{*}{$\begin{array}{l}\text { 5.Cutting } \\
\text { shrubsleaves } \\
\text { or flowers - } \\
\text { Fig.5. }\end{array}$} & \multirow{4}{*}{ 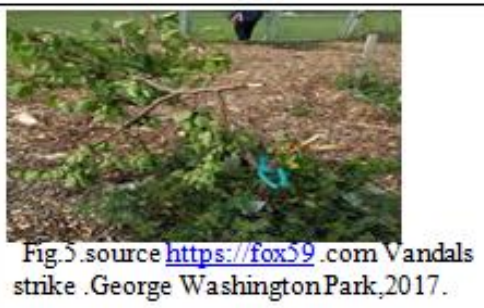 } & Design Mistakes & \multirow{4}{*}{$\begin{array}{l}\text { W Vandal Behaviors } \\
\text { Design Mistakes }\end{array}$} \\
\hline & & & Vandal Behavior & \\
\hline & & & Individual psychosocial & \\
\hline & & & & \\
\hline & \multirow{6}{*}{$\begin{array}{l}\text { 5. Passing } \\
\text { cross it to reach } \\
\text { another space } \\
\text { (in some cases } \\
\text { it can be } \\
\text { forbidden } \\
\text { space)Fig. } 6\end{array}$} & \multirow{6}{*}{$\begin{array}{l}\text { Fig.6.source: Ihe } 200, \mathrm{Egypt} \\
\text { https:/www.youm } 7 . c 0 m / \text { story/2018/2/3. }\end{array}$} & Design Mistakes & \multirow{6}{*}{$\begin{array}{l}\text { - Vandal Behaviors } \\
\text { | Design Mistakes }\end{array}$} \\
\hline & & & Select unsuitable & \\
\hline & & & difficult circulation and & \\
\hline & & & the attractive spaces. & \\
\hline & & & Vandal Behavior & \\
\hline & & & $\begin{array}{l}\text { Individual psychosocial } \\
\text { or eamed behaviors. }\end{array}$ & \\
\hline \multirow{10}{*}{ 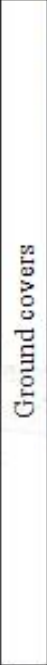 } & \multirow{5}{*}{$\begin{array}{l}\text { 6. Sitting on } \\
\text { ground cover } \\
\text { and cutting } \\
\text { grass, Fig. } 7 \text {. }\end{array}$} & \multirow{5}{*}{ 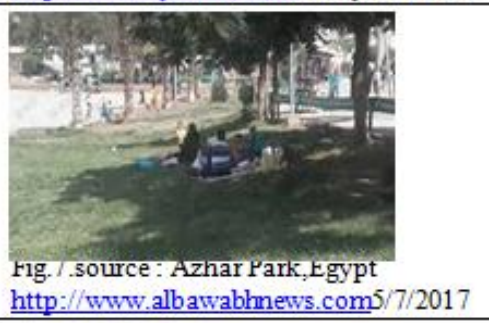 } & Design Mistakes & \multirow{5}{*}{$\begin{array}{l}\text { Wandal Behaviors } \\
\text { w Design Mistakes }\end{array}$} \\
\hline & & & $\begin{array}{l}\text { Not using group seating } \\
\text { areas in the space or } \\
\text { near of ground areas. }\end{array}$ & \\
\hline & & & Vandal Behavior & \\
\hline & & & $\begin{array}{l}\text { Individual psychosocial } \\
\text { or eamed behaviors. }\end{array}$ & \\
\hline & & & & \\
\hline & \multirow{5}{*}{$\begin{array}{l}7 \text { Walking or } \\
\text { sleeping on } \\
\text { ground cover- } \\
\text { Fig. } 8 \text {. }\end{array}$} & \multirow{5}{*}{ 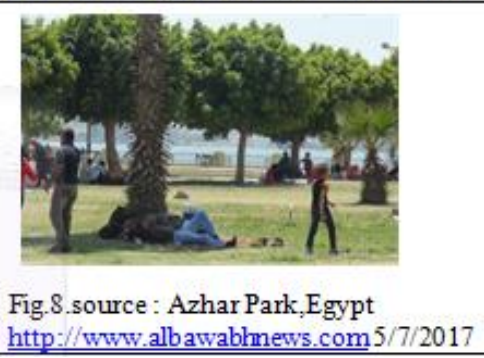 } & Design Mistakes & \multirow{5}{*}{$\begin{array}{l}\text { Wandal Behaviors } \\
\text { a Design Mistakes }\end{array}$} \\
\hline & & & $\begin{array}{l}\text { Width of walkable } \\
\text { paths are not suitable } \\
\text { for full capacity of the } \\
\text { space. }\end{array}$ & \\
\hline & & & Vandal Behavior & \\
\hline & & & $\begin{array}{l}\text { Individual psychosocial } \\
\text { or eamed behaviors. }\end{array}$ & \\
\hline & & & & \\
\hline
\end{tabular}

\subsubsection{Water features}

Water in the landscape is a vital element in a balanced garden. It enhances the appearance of a landscape, purifies air, reduces noise pollution, besides other things, as.. Water features add sound, texture, and movement to landscaping designs and help users to feel that their surroundings are more natural and unique [10]. 
JES, Assiut University, Faculty of Engineering, Vol. 47, No. 2, March 2019, pp. 218-235

Table 3.

Classification of Water elements due to vandal actions - source :Author adapted by Collin Yard.

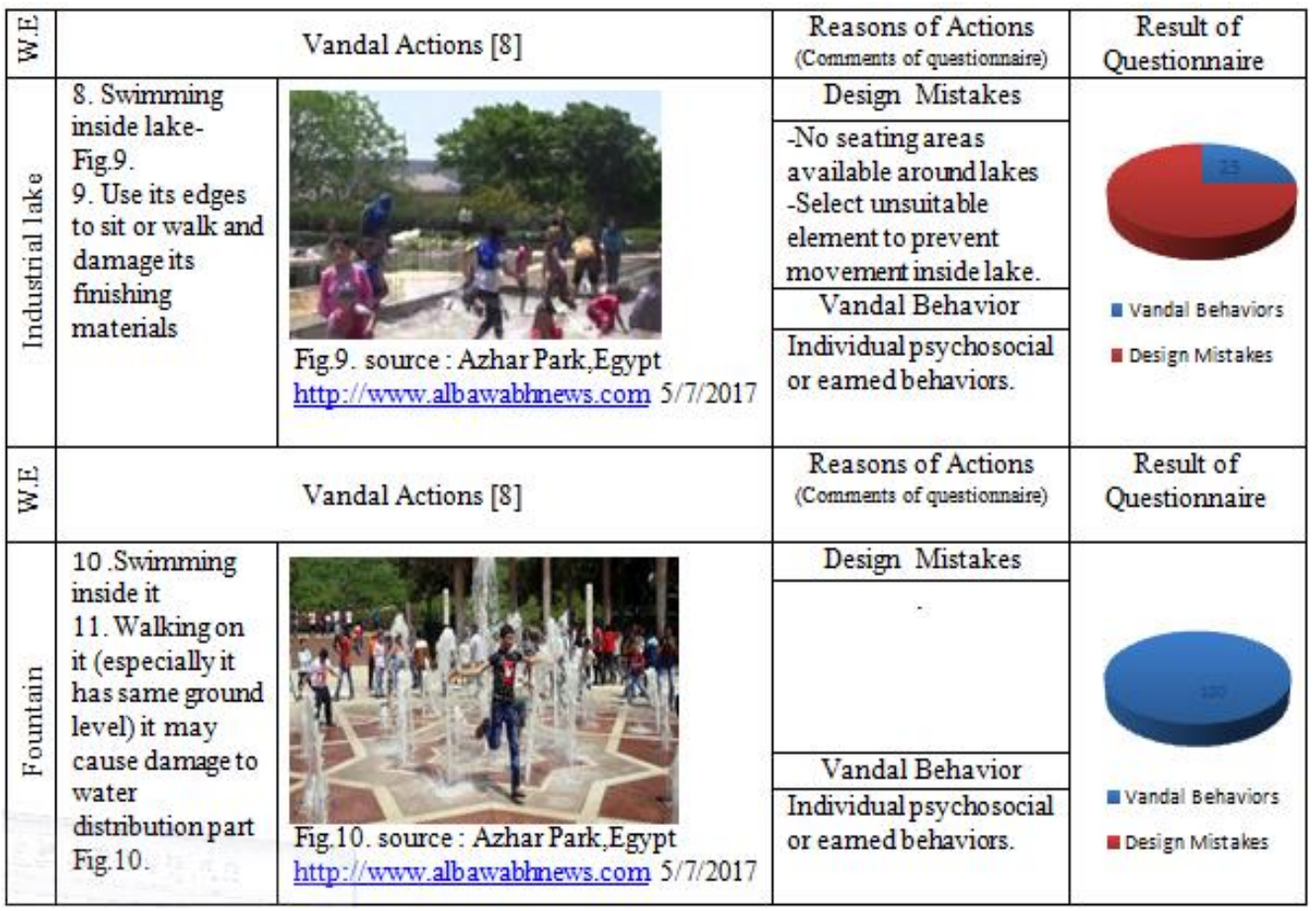

\subsubsection{Hardscape elements}

A hardscape is design that is constructed using natural and man-made, non-living materials. Hardscape includes landscaping details such as stone or concrete walkways, decks, retaining walls, patios, and other landscaping designs that use stone, wood, sand, pebbles, brick, metal, and other similar materials [11].

\section{Table 4.}

Classification of Hardscape elements due to vandal actions source :Author adapted by Collin Yard.

\begin{tabular}{|c|c|c|c|c|}
\hline 닢 & & Vandal Actions [8] & $\begin{array}{l}\text { Rea sons of Actions } \\
\text { (Comments of questionnaire) }\end{array}$ & $\begin{array}{c}\text { Result of } \\
\text { Questionnaire }\end{array}$ \\
\hline \multirow{6}{*}{ 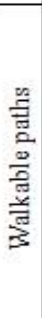 } & \multirow{6}{*}{$\begin{array}{l}\text { 12.Breaking } \\
\text { finishing } \\
\text { materials. } \\
\text { 13. Use it in } \\
\text { another function } \\
\text { effect on its } \\
\text { materials which } \\
\text { are not suitable } \\
\text { for the new } \\
\text { function. } \\
\text { 14. Sitting-Fig.11. }\end{array}$} & \multirow{6}{*}{$\begin{array}{l}\text { Fig.11.source: The Zoo, Lgypt } \\
\text { https://www.youm } 7 . c o m / \text { story/2018/2/3. }\end{array}$} & Design Mistakes & \multirow{6}{*}{$\begin{array}{l}\text { I Vandal Behaviors } \\
\text { - Design Mistakes }\end{array}$} \\
\hline & & & $\begin{array}{l}\text { No seating areas } \\
\text { available aroumd paths }\end{array}$ & \\
\hline & & & & \\
\hline & & & Vandal Behavior & \\
\hline & & & Individualpsychosocial & \\
\hline & & & or eamed behaviors. & \\
\hline \multirow{5}{*}{ 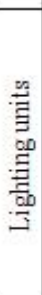 } & \multirow{5}{*}{$\begin{array}{l}\text { 15. Damage or } \\
\text { break lighting } \\
\text { units Fig. } 12 \text {. } \\
\text { 16. Damage of } \\
\text { lighting wires. }\end{array}$} & \multirow{5}{*}{ 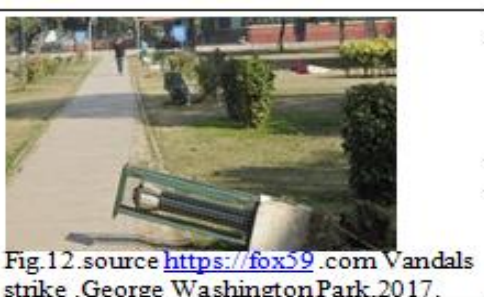 } & Design Mistakes & \multirow{5}{*}{$\begin{array}{l}\text { - Vandal Behaviors } \\
\text { I. Design Mistakes }\end{array}$} \\
\hline & & & & \\
\hline & & & & \\
\hline & & & Individual psychosocial & \\
\hline & & & or eamed behax & \\
\hline
\end{tabular}


Table 4. (Cont)

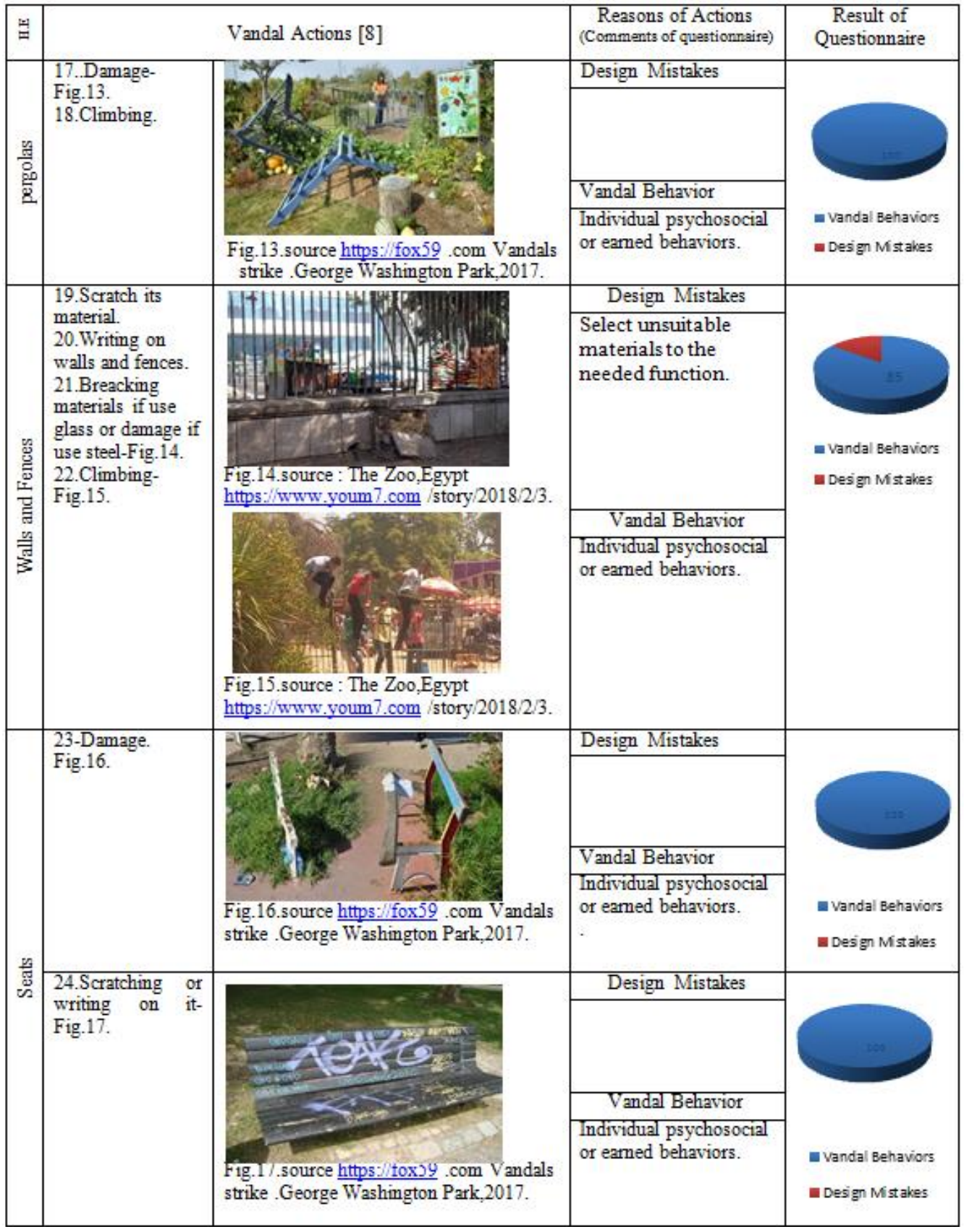


JES, Assiut University, Faculty of Engineering, Vol. 47, No. 2, March 2019, pp. 218-235

Table 4. (Cont)

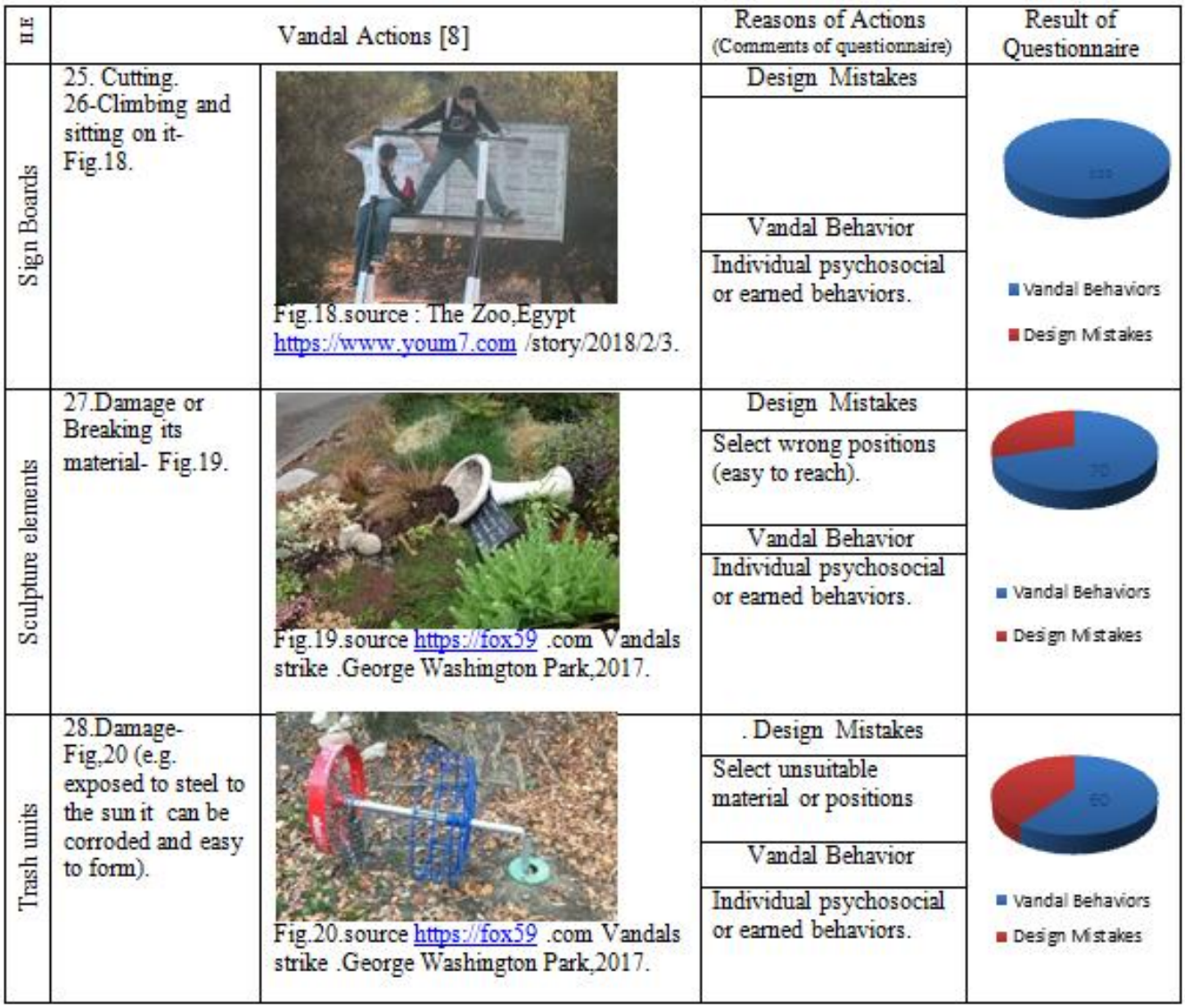

From previous tables the reasons of vandal actions to the landscape elements differ between design mistakes $(22.3 \%)$ or users behaviors $(77.7 \%)$ depends on user's culture, Psychosocial, and community around them, as shown in Fig.21.

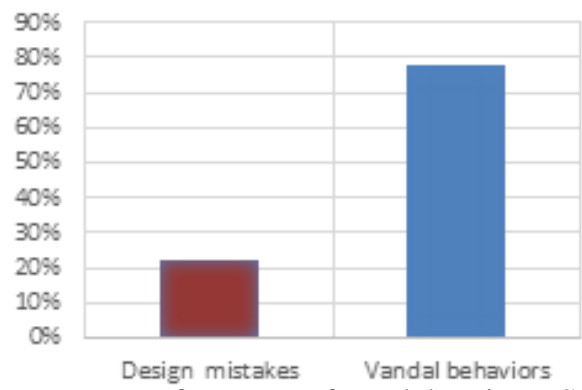

Fig. 21..Percentage of reasons of vandal action - Source :Author.

\subsection{Design Suggestions To Reducing Vandal Actions In Open Landscape Spaces}

With the existence of controlling solutions from the supervision authority, but it was not affected with full capacity of users especially in occasions and celebrations times, therefore the designer must find new alternatives ways in design landscape of urban open spaces to prevent these behaviors towards landscape elements either by choosing them or 
choosing their appropriate places during the design process. The following table list some of design suggestions to prevent or reduce vandal actions - Table.5 :

Table 5.

Design suggestions to reduce vandal actions - Source :Author adapted by Collin Yard [8].

\begin{tabular}{|c|c|c|}
\hline LS.E & Vandal actions & Design Suggestions \\
\hline \multirow{3}{*}{ 鲁䱛 } & 1.Climb trees and palms. & $\begin{array}{l}\text { 1. Pamt the bottom of trees and palms with soft materials prevent clambing } \\
\text { on it (but in the same time the material not effest on the arowth of planets). }\end{array}$ \\
\hline & 2.Scratth trees and palms. & $\begin{array}{l}\text { 1. Pamt the bottom of trees and palms (in the level of human actions) with } \\
\text { materials don't affected with seratches of writing on. }\end{array}$ \\
\hline & $\begin{array}{l}\text { 3.Wrnte or picking lowers } \\
\text { and leaves. }\end{array}$ & $\begin{array}{l}\text { 1. Protection with fences of plants or solid materials around the trets. (Tree } \\
\text { Surrounded) }\end{array}$ \\
\hline \multirow[b]{2}{*}{$\frac{g^{2}}{\frac{5}{n}}$} & $\begin{array}{l}\text { 4.Cutting shaubs leaves or } \\
\text { llowers. }\end{array}$ & $\begin{array}{l}\text { 1.Design linear shrubs with large width and put lowers sharbs in the midde } \\
\text { of it to cannot reach it. }\end{array}$ \\
\hline & $\begin{array}{l}\text { 5.Passmg cross it to reach } \\
\text { another space (in some } \\
\text { cases it can be forbidden } \\
\text { space). }\end{array}$ & 1-Use type of shrubs with sharp texture to harm when passmg it. \\
\hline \multirow{2}{*}{ 沓 } & $\begin{array}{l}6 . \text { Sitting on ground cover } \\
\text { and cutting grass. }\end{array}$ & $\begin{array}{l}\text { 1.Divided large are2s of grass covered into small areas. } \\
\text { 2.Design circular seats around trees but by considering the irrigation system. }\end{array}$ \\
\hline & $\begin{array}{l}\text { 7.Walking or sleeping on } \\
\text { ground cover. }\end{array}$ & $\begin{array}{l}\text { 1Design enough space to walkable paths (depends on studymg the full } \\
\text { capacity of spaces) and isolated the green area with suitable elements } \\
\text { prevent users from reach it. }\end{array}$ \\
\hline 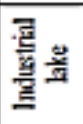 & $\begin{array}{l}\text { 8.Swimming mside lake. } \\
\text { 9.Use its edges to sit or } \\
\text { walk and damage its } \\
\text { fmishing materials. }\end{array}$ & $\begin{array}{l}\text { 1.Providmg sitting areas at the sides of the lakes. } \\
\text { 2.Design effective edges or make it from material prevent users from } \\
\text { moving through (such } 23 \text { some types of shrubs with sharp edges or large } \\
\text { width). }\end{array}$ \\
\hline 夏 & $\begin{array}{l}\text { 10.Swimming mside it. } \\
11 \text {. Walking on it (especially } \\
\text { it has same ground level) it } \\
\text { may cause damage water to } \\
\text { distribution part). }\end{array}$ & $\begin{array}{l}\text { 1.Put water distribution part under ground level to protect it from users } \\
\text { walking. } \\
\text { 2.Design foumtain with many different levels and with design prevent } \\
\text { standing in it. }\end{array}$ \\
\hline 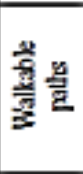 & $\begin{array}{l}\text { 12.Breakmg funishing } \\
\text { materials. } \\
13 . \text { Sse it in another function } \\
\text { (play football) effect on its } \\
\text { materials. } \\
14, \text { Sitting on paths. }\end{array}$ & $\begin{array}{l}\text { 1. Use sofrmaterial to make to easy to walk on to avoid usmg another llegal } \\
\text { path. } \\
\text { 2. Design paths with variable width and distribute plants and seats through it } \\
\text { (to make use another activity is so difficult). }\end{array}$ \\
\hline 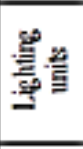 & $\begin{array}{l}\text { 15.Damage of break lighting } \\
\text { units. } \\
\text { 16.Damage of lighting } \\
\text { wires. }\end{array}$ & $\begin{array}{l}\text { 1.Selectet the place of it in drficult position to reach (mside walls or Skelion } \\
\text { - above fence). } \\
\text { 2. High enough to protect it from damage. } \\
\text { 3. Use of hard-brealking lighting units. } \\
\text { 4.Hide wires completely. }\end{array}$ \\
\hline 递 밸 & $\begin{array}{l}\text { 17.Damage. } \\
\text { 18.Climbing. }\end{array}$ & $\begin{array}{l}\text { 1. Panting bottom of columins (in the level of human actions) with anti- } \\
\text { scratch materials and with soft texture to avoiding climb. } \\
\text { 2. Increase the height of horizontal members of pergola to cannot reach. }\end{array}$ \\
\hline 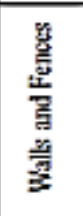 & $\begin{array}{l}\text { 19.Scratch its material. } \\
20 \text {. Writing on walls and } \\
\text { fences. } \\
\text { 21.Breacking materials if } \\
\text { use glass of damage if use } \\
\text { steel. } \\
\text { 22. Climbing. }\end{array}$ & $\begin{array}{l}\text { 1.Use material anti scratch or writing and easy to clean. } \\
\text { 2.Use hard materials difficult to broken with simple tools. } \\
\text { 3.Don't use finishing materials easy to remove such as ceramic. } \\
\text { 4.Make longitudinal design and dificult to climb. } \\
\text { 5.Allow openings in it at suitable distance to move from space to another to } \\
\text { avoiding damage. } \\
\text { 6.Painting walls with different colors (same color encourage writing on it). }\end{array}$ \\
\hline 总 & $\begin{array}{l}\text { 23.D magae. } \\
\text { 24. Seratehing or writing on } \\
\text { it. }\end{array}$ & $\begin{array}{l}\text { 1.Painting it with material ant scratch or writing and easy to clean. } \\
\text { 2. Use hard materials difficult to broken with simple tools. }\end{array}$ \\
\hline$\frac{5}{\frac{5}{5}}$ & $\begin{array}{l}\text { 25.Cutting. } \\
26 . \text { Climbing and sitting on } \\
\text { it. }\end{array}$ & $\begin{array}{l}\text { 1. Uelecet the place of it in difficult position to reach (very high - above } \\
\text { other elements) and hide installation elements. } \\
\text { 2.Must use high resistance materials and easy to maintenance. }\end{array}$ \\
\hline 氶莒 & $\begin{array}{l}\text { 27.Damage or Breaking its } \\
\text { material. }\end{array}$ & $\begin{array}{l}\text { 1.Select places dificult to reach (surrounded by plants or bardscape } \\
\text { elements. }\end{array}$ \\
\hline 窗总 & $\begin{array}{l}\text { 2S.Damage (e.g. exposed to } \\
\text { steel to the sun it can be } \\
\text { corroded and easy to form). }\end{array}$ & $\begin{array}{l}\text { 1.Use air resistance materials. } \\
\text { 2.Prefer to put it underground. }\end{array}$ \\
\hline
\end{tabular}




\section{Impact of applying design suggestions on maintenance of landscape elements}

Landscape maintenance is the art of keeping a landscape healthy, clean, safe and attractive, Using tools, supplies, knowledge, physical exertion and skills

Attractively designed, healthy, and well-maintained landscape create a positive first impression, establish a peaceful mood, and increase property value. Maintaining landscape is essential to the health and growth of landscape investment and help spaces to perform its function in the most successful manner [12].

Maintenance tasks must be set within the overall project objectives and it should be divided into sub -duties that must be carried out by all those who operate the maintenance management, and it can be said that the main responsibility of each member of the maintenance department is to contribute to enable the project to achieve a goal [13].

\subsection{Classification of landscape elements maintenance}

There is more than one classification for landscape maintenance. These differed on the nature of maintenance tasks, the time of maintenance and differs between landscape elements types [12].

\subsubsection{First classification: divided into three main types}

- Main repairs: Major repairs of the building's components and elements, such as repair retaining walls or re-paving paths. This type usually includes improvements and additions tasks.

- Repetition maintenance: This maintenance is performed periodically and is often based on the life cycle of the different elements or materials used.

- Daily maintenance: used to prevent any landscape defect or to help elements to achieve needed functions such as irrigation, tree trimming, etc.

\subsubsection{Second classification: divided into two basics types only}

- Predictable maintenance tasks: consist of regular maintenance works that are necessary to maintain the performance of materials and elements, in addition to repairs and replacements tasks which depends on elements and materials lifecycle.

- Preventive maintenance tasks: maintenance tasks we can prevent or avoiding it, and resulting from design mistakes, implementation errors, or use materials with wrong slandered specification.

\subsection{Maintenance of planet elements}

Plants maintenance tasks differs upon the reasons of maintenance to growth, repair, treatment.... Etc as shown in Table 6.

\subsubsection{Maintenance for growth}

Plants needs to successfully growth a lot of maintenance tasks differs in growth rate of the individual's elements, plant size structure, plant surrondes, plant density and species composition in plant communities [14]. These tasks divided into five main axes: Cutting and removing harmful plants, shaping operations, Cleaning operations (collection of leaves), Irrigation operations, fertilization and pesticides as shown in Fig.22. 


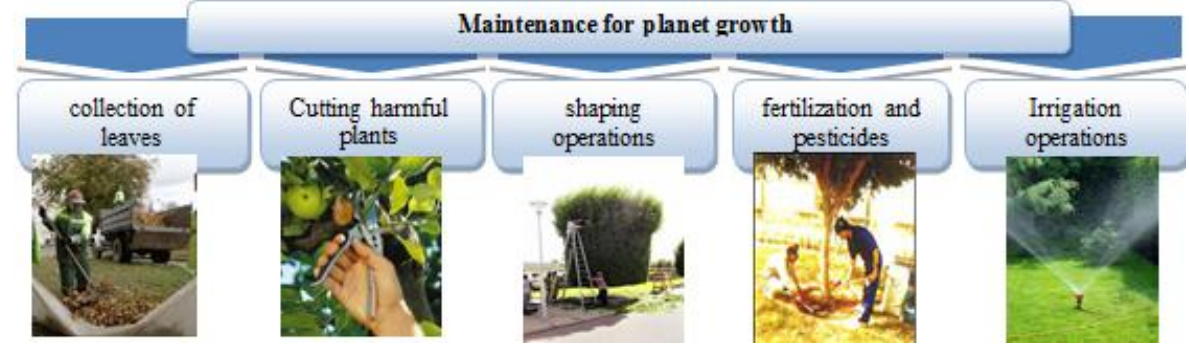

Fig. 22. Maintenance tasks of planet growth - source:Author adapted by Phillips .L [15]

\subsubsection{Trees treatment}

Tree disease treatment is only effective when targeted for type of tree, specific disease and desired outcome. Professional treatments can help protect landscape investment and enhance property value [16]. Damage may Cause By: physical injury to the trunk and crown, soil compaction in the root zone, severed roots, smothered roots from added fill soil, insects [17].

\subsubsection{Replacement of planet elements}

partial or total replacement of the plant elements, whether the reason for the end of elements life cycle or the vandalism actions caused partially or completely damaged and prevent the element to perform its function in the space[14].

Table 6.

Classification of Planet Maintenance tasks - source :Author.

\begin{tabular}{|c|c|c|c|c|c|c|c|c|}
\hline \multicolumn{2}{|c|}{ Maintenance of Planet elements } & $\begin{array}{l}\text { Irrigation } \\
\text { operations }\end{array}$ & fertilizasion & $\begin{array}{c}\text { shaging } \\
\text { operations }\end{array}$ & $\begin{array}{l}\text { removing } \\
\text { harmfuil } \\
\text { plants }\end{array}$ & $\begin{array}{l}\text { Cleaning } \\
\text { operations }\end{array}$ & trestment & Replacement \\
\hline \multirow{2}{*}{$\begin{array}{l}\text { Maintena } \\
\text { nce } \\
\text { Classific } \\
\text { ation } \\
\end{array}$} & $\begin{array}{c}\text { Predictable } \\
\text { maintenance tasks }\end{array}$ & $*$ & * & * & $*$ & $*$ & & \\
\hline & $\begin{array}{c}\text { Preventive } \\
\text { maintenance tasks }\end{array}$ & & & & & & * & * \\
\hline
\end{tabular}

\subsection{Maintenance of water features}

Water feature need weekly maintenance, with more work at the beginning and end of the growing season in cold-weather climates. maintenance tasks can be divided into main points [18], as shown in Table 7:

clean the water is the most important items of water maintenance, as the dirt and leaves of trees works on the blockage and effect on water flow. use chemicals in the cleaning of the water element to eliminate the bacteria.

Maintenance of water push devices or parts, whether in fountains to prevent clogging.

Maintenance of motors in case of moving water.

Replacement or repair finishing materials of water container 
JES, Assiut University, Faculty of Engineering, Vol. 47, No. 2, March 2019, pp. 218-235

\section{Table 7.}

Classification of water Maintenance tasks - source :Author.

\begin{tabular}{|c|c|c|c|c|c|c|c|}
\hline \multicolumn{2}{|c|}{ Maintenance of Water features } & \multirow{2}{*}{$\begin{array}{c}\begin{array}{c}\text { Regular } \\
\text { Cleanliness }\end{array} \\
*\end{array}$} & \multirow{2}{*}{$\begin{array}{l}\text { Cleanliness } \\
\text { due to } \\
\text { wrong use }\end{array}$} & \multirow{2}{*}{$\begin{array}{c}\text { Regular } \\
\text { maintenance } \\
\text { of water } \\
\text { motors and } \\
\text { water outlets }\end{array}$} & \multirow{2}{*}{$\begin{array}{c}\text { Replacement } \\
\text { or repair of } \\
\text { water outlets } \\
\text { due to wrong } \\
\text { use } \\
\end{array}$} & \multirow{2}{*}{$\begin{array}{l}\text { Repair of } \\
\text { finishing } \\
\text { materials }\end{array}$} & \multirow{2}{*}{$\begin{array}{c}\begin{array}{c}\text { Replacement } \\
\text { of finishing } \\
\text { materials }\end{array} \\
* *\end{array}$} \\
\hline $\begin{array}{c}\text { Maintena } \\
\text { nce }\end{array}$ & $\begin{array}{c}\text { Predictable } \\
\text { maintenance tasks }\end{array}$ & & & & & & \\
\hline $\begin{array}{l}\text { Classific } \\
\text { ation }\end{array}$ & $\begin{array}{c}\text { Preventive } \\
\text { maintenance tasks }\end{array}$ & & $*$ & & * & * & \\
\hline
\end{tabular}

\subsection{Maintenance Of Hardscaping Elements}

Maintenance tasks can be divided into main points [12], as shown in Table.8 : Cleanliness, Replacement or repair finishing material included painting depends on element life cycle, but sometimes we need to make maintenance before this time due to many factors (e.g. Pergolas need to be repaired and painted if affected by weather factors lighting units need to change in the case of damage)[9].

\section{Table 8.}

Classification of Hardscape Maintenance tasks - Source :Author.

\begin{tabular}{|c|c|c|c|c|c|}
\hline \multicolumn{2}{|c|}{$\begin{array}{l}\text { Maintenance of Hardscape } \\
\text { elements }\end{array}$} & \multirow{2}{*}{$\begin{array}{c}\text { Regular Cleanliness } \\
*\end{array}$} & \multirow{2}{*}{$\begin{array}{c}\text { Replacement or } \\
\text { repair of finishing } \\
\text { materials due to life } \\
\text { cycle } \\
\text { * }\end{array}$} & \multirow[t]{2}{*}{$\begin{array}{l}\text { Repair or painting } \\
\text { finishing materials } \\
\text { due to wrong use }\end{array}$} & \multirow[t]{2}{*}{$\begin{array}{l}\text { Replacement of } \\
\text { finishing materials } \\
\text { due to wrong use }\end{array}$} \\
\hline $\begin{array}{c}\text { Maintena } \\
\text { nace }\end{array}$ & $\begin{array}{c}\text { Predictable } \\
\text { maintenance tasks }\end{array}$ & & & & \\
\hline $\begin{array}{l}\text { Classific } \\
\text { ation }\end{array}$ & $\begin{array}{c}\text { Preventive } \\
\text { maintenance tasks }\end{array}$ & & & $*$ & $*$ \\
\hline
\end{tabular}

\subsection{Suggested Solutions And Its Effect Of The Reduction Of Maintenance Tasks}

From previous tables study suggested some solutions to prevent vandalism actions towards landscape elements in open spaces, the following table measure impact of applied design solutions on reduce plan of landscape maintenance, Table.9 . 
Table 9.

Impact of applied design solutions on reduce landscape maintenance - source :Author.

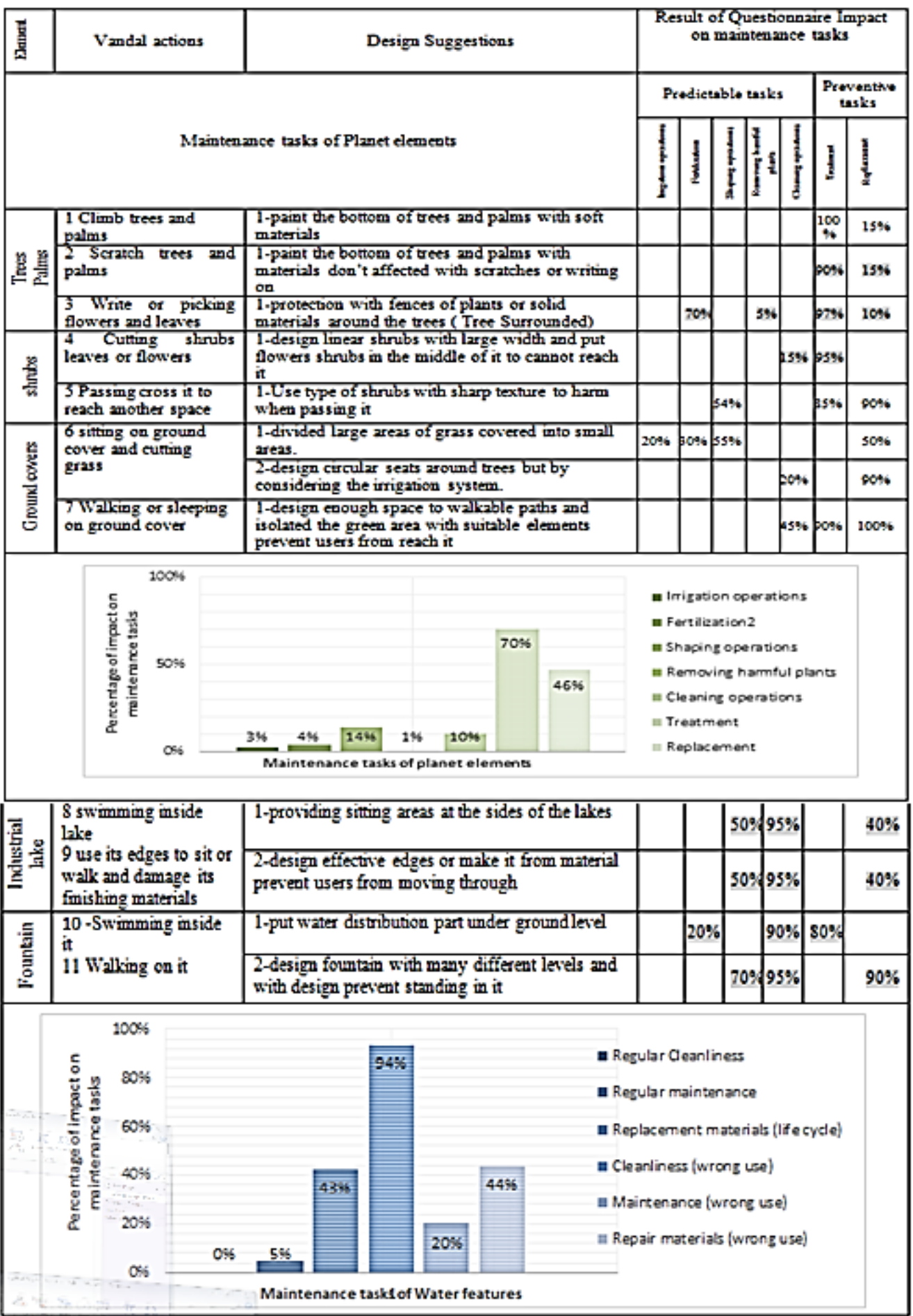


JES, Assiut University, Faculty of Engineering, Vol. 47, No. 2, March 2019, pp. 218-235

Table 9. (Cont)

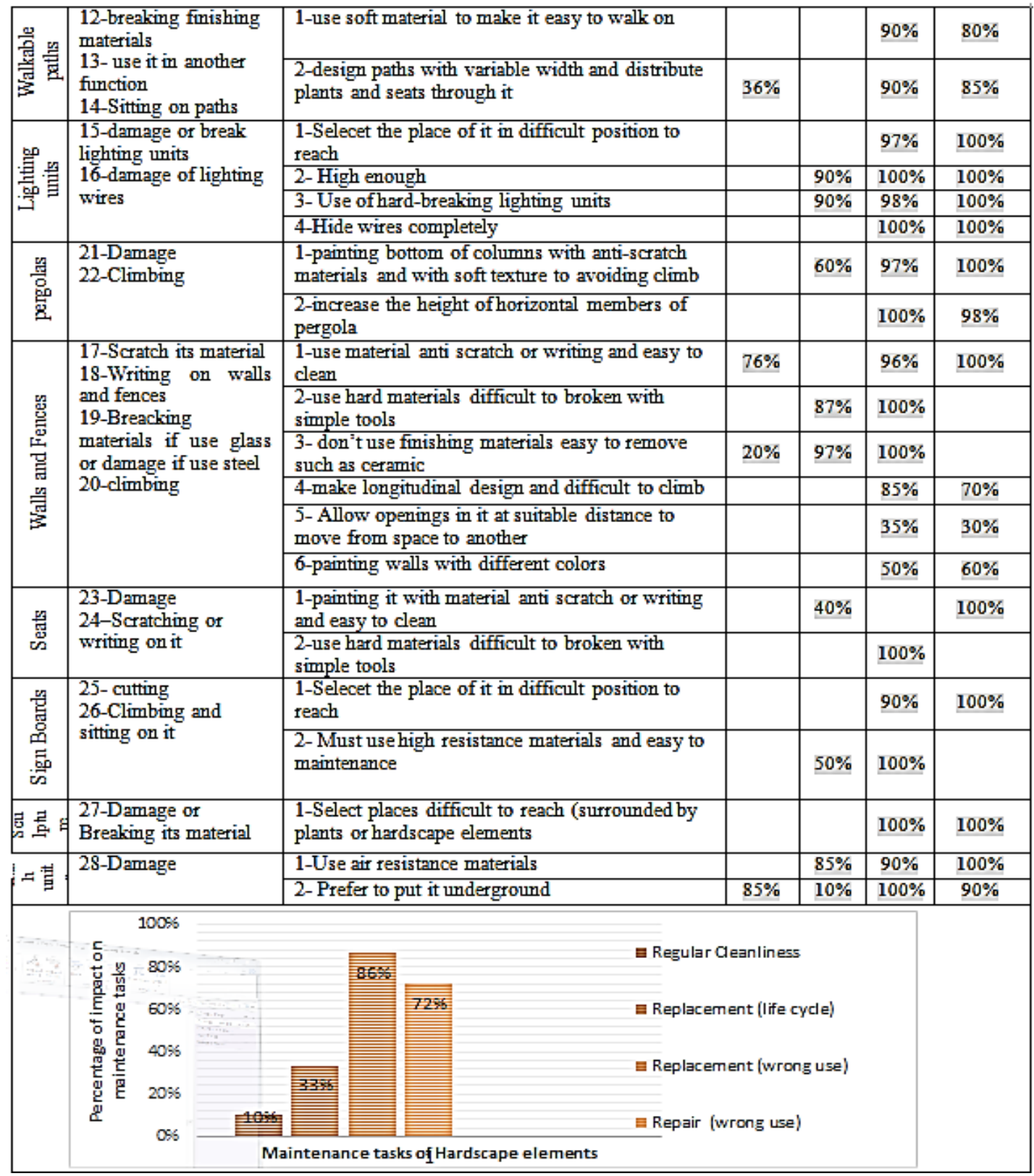

From previous tables:

- Most of plant maintenance tasks related to growth of plants (Predictable maintenance tasks) so it doesn't affect with user's vandal actions but in another side, actions have a major impact on elements life cycle and aesthetics factors which lead to total or partial replacement as shown in Fig.23.

- Vandalism actions affected maintenance task of water and hardscape elements which follow the second classification of maintenance. The implementation of design solutions can reduce the impact of behaviors towards the elements and 
thus reduce the maintenance of the elements gradually either by save life cycle or reduce the replacement, repaired and painting operations as shown in Fig.23.

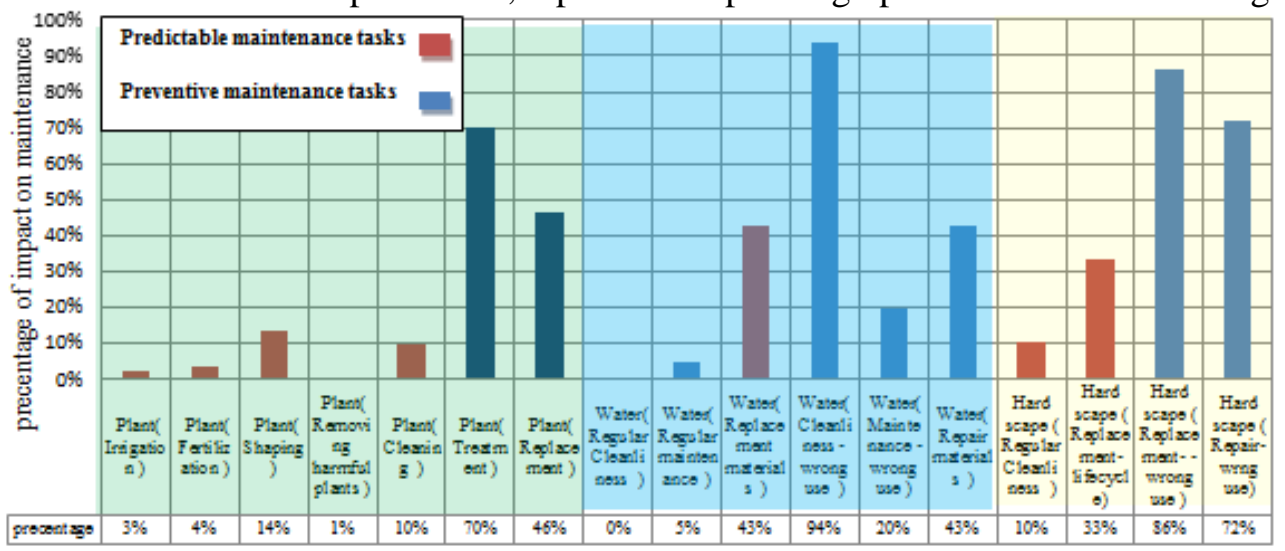

Fig. 23. The difference between the impact of design suggested on predictable and preventive maintenance tasks - Source :Author.

\section{Results}

Urban open space is one of the basic requirements for environmental, functional, social, psychological, aesthetic and economic needs for healthy and balanced life. Therefore, the design of the urban open space must be based on the study of users' needs and expected positive or negative behavior from users. Vandal behaviors affected landscape elements in different aspects, aesthetic or functional or climate and prevents the performance of activities which urban open space designed for. So, designer must analyze the reasons of vandal behaviors towards urban spaces whether it due to social, religious, cultural or educational user's factors or design factors, vandal behaviors may be considered as strong indicator for the designer in achieving user's requirements in the space.

Although there are controlling solutions from the supervision authority, but it was not affected with full capacity of users especially in occasions and celebrations times, therefore the designer must find new alternatives ways in design landscape of urban open spaces to prevent these behaviors towards landscape elements either by choosing elements or choosing their appropriate places during the design process.

Landscape maintenance tasks has a major impact on project cost and function, therefor tasks must be set within the overall project objectives. Maintenance tasks divide into two main classifications Predictable maintenance tasks which consist of regular maintenance works and Preventive maintenance tasks which mean tasks that we can prevent or avoiding it, and resulting from design mistakes, implementation errors, or use materials with wrong standard specification- Fig 24.

\begin{tabular}{|c|c|c|c|c|c|c|c|c|c|c|}
\hline \multirow{3}{*}{$\begin{array}{l}\text { Maintenance tasks of } \\
\text { Planet elements }\end{array}$} & \multicolumn{2}{|c|}{ Predictable tasks } & \multicolumn{8}{|c|}{ Preventive tasks } \\
\hline & $\begin{array}{l}\text { Irrigation } \\
\text { operations }\end{array}$ & Fertilization & \multicolumn{2}{|c|}{$\begin{array}{c}\text { Shaping } \\
\text { operations }\end{array}$} & \multicolumn{2}{|c|}{$\begin{array}{c}\text { Removing } \\
\text { harmful } \\
\text { plants }\end{array}$} & \multicolumn{2}{|c|}{$\begin{array}{l}\text { Cleaning } \\
\text { operations }\end{array}$} & Treatment & Replacement \\
\hline & \multicolumn{5}{|c|}{ Predictable tasks } & \multicolumn{5}{|c|}{ Preventive tasks } \\
\hline \multirow{3}{*}{$\begin{array}{l}\text { Maintenance tasks of } \\
\text { Hard scape elements }\end{array}$} & $\begin{array}{l}\text { Regular } \\
\text { Cleanliness }\end{array}$ & $\begin{array}{r}\text { Regul } \\
\text { maintens }\end{array}$ & & $\begin{array}{l}\text { Repla } \\
\text { nt mat }\end{array}$ & & $\begin{array}{r}\text { Clean } \\
\text { (w } \\
u\end{array}$ & $\begin{array}{l}\text { liness } \\
\text { rong } \\
\text { se) }\end{array}$ & & $\begin{array}{l}\text { intenance } \\
\text { wrong } \\
\text { use) }\end{array}$ & $\begin{array}{c}\text { Repair } \\
\text { materials }\end{array}$ \\
\hline & \multicolumn{5}{|c|}{ Predictable tasks } & \multicolumn{5}{|c|}{ Preventive tasks } \\
\hline & $\begin{array}{l}\text { Regul } \\
\text { Cleanlir }\end{array}$ & & Repla & $\begin{array}{l}\text { cement } \\
\text { cycle) }\end{array}$ & & & $\begin{array}{l}\text { eplaces } \\
\text { vrong }\end{array}$ & & Repz & (wrong use) \\
\hline
\end{tabular}

Fig. 24. Maintenance tasks of landscape elements- Source :Author. 
- The vandalism greatly affects the aesthetics and the life cycle of the element. The study proof that by applying the design solutions, we can reduce the vandalism phenomenon towards the elements and thus reduce the maintenance tasks at a large rate.

- Most of plant maintenance tasks doesn't affected with user's vandal actions but actions have a major impact on elements life cycle and aesthetics factors which lead to total or partial replacement. On the other side vandalism actions has a great effect on second classification of maintenance in water elements and hardscape elements. The implementation of design solutions can reduce the impact of behaviors towards the elements and thus reduce the maintenance of the elements gradually either by preserve life cycle or reduce the replacement, repaired and painting operations.

\section{REFERANCE}

[1] Krier. R,” Urban Space”, Rizzoli International Publications, Ink. New York,1979.

[2] Panduro.T.E.," Classification and Valuation Of Urban Green Spaces", Hedonic house price valuation, IFRO, University of Copenhagen, Working Paper, 2013.

[3] Istvan.P.and Takacs.D., "The Significance Of Urban Open Spaces And Green Areas In Urban Property Development"-First International Conference Horticulture and Landscape Architecture in Transylvania-Agriculture and Environment Supplement, 2011.

[4] Bakhtiyari.A., "Preventing Vandal Behaviors by Emphasizing on Environmental Design Methods -Case study: Mashhad Metropolitan", International Journal of Scientific \& Engineering Research Vol.8, No.5, 2017

[5] Yavuz.A. and Kuloğlu.N., "The effects of locational factors on vandalism in the seaside parks" Scientific Research and Essays Vol. 6, 2011.

[6] Moradi,N."Security indicators in urban spaces ".shahrdariha 2002.

[7] Faizi.M., Hosseini.S. and Asl. S."Identification Of Environmental Design Methods and Techniques For Preventing Vandalism" Iranian University of science and Technology, 2008.

[8] Yard. C, Vandalism, Van Nostrand Reinhold Co. New York, 1973.

[9] Waterman.T., "The Fundamentals of Landscaper Architecture “, AVA Publishing SA, Switzerland, 2009.

[10] Koskina A. and N. Hasanagas," The Water Element as Aesthetic Factor In Landscape Design “, University of Alba Iulia, 2013.

[11] Editors of Creative Homeowner, Landscaping "Ultimate Guide: Walks, Patios \& Walls", Creative Homeowner - A Division of Federal Markting Corp - May 2010.

[12] Hwww.cabmphandbooks.com ,'Landscape Maintenance", January 2003 California Storm water BMP Handbook. p3

[ 13] Miller.L ," Landscape Design Combinations Paperback" - January 13, 2017 .

[14] Lötscher.M , Klumpp.K and Schnyder.H. ," Growth And Maintenance Respiration For Individual Plants In Hierarchically Structured Canopies Of Medicago Sativa “, http: newphytologist.org, 2004.

[15] Phillips .L ,"Parks: Design And Management" McGraw-Hill Ink,U.S.A,1996 .

[16] "Treatment of Trees Damaged By Construction", brochure, www.treesaregood.org, 2011.

[17] Sinclair.W, Howard H. Lyon," Diseases of Trees and Shrubs, Second Edition (Comstock Book)", AVA Publishing SA, Switzerland.2005

[18]"Landscape Maintenance" California Storm water BMP Handbook Municipa.p3 www.cabmphandbooks.com , 2003. 


\section{التصميم ضد التخريب كمدخل لصيانة تنسيق الموقع بالفراغات العمرانية المفتوحة}

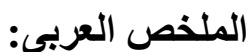

تعد الفر اغات الحضرية المفتوحة في المحيط العمراني المتنفس الطبيعي للإنسان لمحاكاة الطبيعة وللقيام

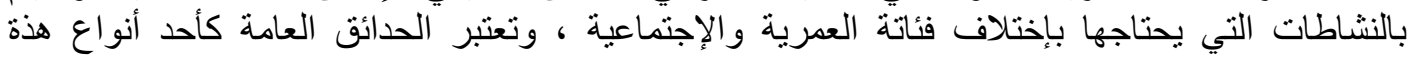

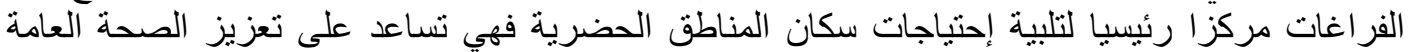

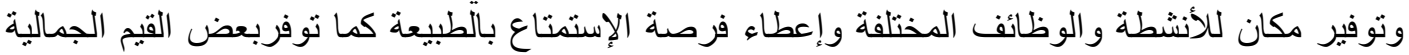

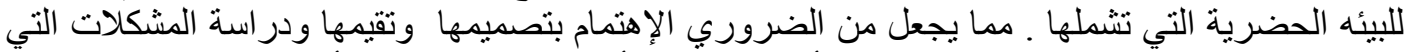

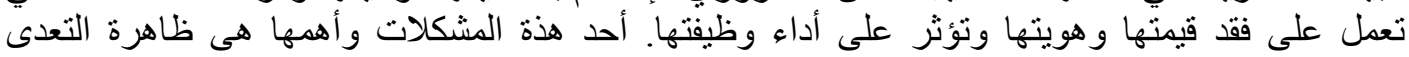

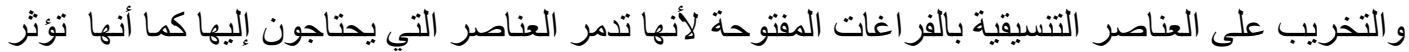

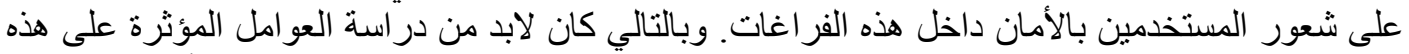

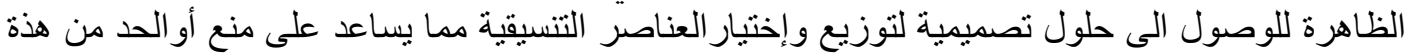

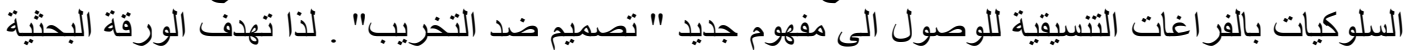
لتحليل أسباب حدوث التخريب ضد عناصر تنسيق الموقع وإستخلاص مجموعة من الحلول التصميفيميه

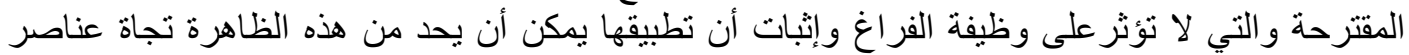

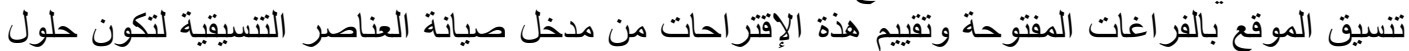

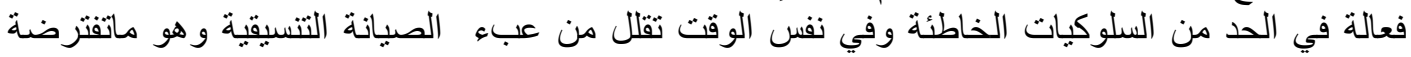
الورقة البحثية . 